\title{
䊦
}

\section{Om die Psalms biddend te sing of singend te bid}

\author{
Paul Styger \\ Sentrum vir BWI \\ Potchefstroomkampus \\ Noorwes-Universiteit \\ POTCHEFSTROOM \\ E-pos: bwips@puk.ac.za
}

\author{
Dirk Human \\ Dept. Ou-Testamentiese Wetenskap \\ Fakulteit Teologie \\ Universiteit van Pretoria \\ PRETORIA \\ E-pos: djhuman@ccnet.up.ac.za
}

\section{Abstract}

To pray the Psalms singing or sing the Psalms praying

The aim of this paper is to investigate the singing of the Psalms, during the church service in the light of the fact that the Psalter is viewed as a prayer book. Firstly, the psalm as prayer is discussed and it is shown that the Psalms play an important role in the Christian church and its liturgy. The views of Calvin and Luther on prayer in general and the singing and praying of the Psalms in particular, are discussed. The views of a few other researchers are highlighted. The conclusion is made that the singing of a psalm in the church service is a public, but personal conversation with God. With regard to this conclusion, the singing of the Psalms in the church service today is discussed and recommendations are made. The use of the Psalms as liturgical song places a very big responsibility on the preacher to ensure that the prayer character of the psalm as personal public conversation with God is recognised in the liturgy. Care must be taken to ensure that the singing of the Psalms in the liturgy does not degrade to a thoughtless, unrespectful custom.

\section{Opsomming}

Om die Psalms biddend te sing of singend te bid

Die doel van hierdie artikel is om die sing van die Psalms in die erediens te ondersoek in die lig van die feit dat die Psalter as 'n gebedeboek beskou word. Eerstens word die psalm as gebed bespreek en daar word gewys dat die Psalms 'n kernrol speel in die Christelike kerke se liturgie. Die sienings van Calvyn en Luther oor die gebed in die algemeen en die sing en bid van die 
Psalms in die besonder, word bespreek. Enkele ander skrywers se sienings word ook bespreek. Die gevolgtrekking is dat die sing van 'n psalm in die erediens 'n openbare, maar persoonlike gesprek met God is. In die lig hiervan word die sing van die Psalms in die erediens vandag bespreek en aanbevelings word gemaak. Die gebruik van die Psalms as liturgiese lied plaas 'n baie groot verantwoordelikheid op die liturg om te waak dat die gebedskarakter van die psalm as persoonlike openbare gesprek met God nie misken word nie. Daar moet gewaak word dat daar nie verval word in 'n onnadenkende, oneerbiedige gewoontehandeling wanneer die Psalms in die erediens gesing word nie.

Hence it is perfectly clear that neither words nor singing (if used in prayer) are of the least consequence, or avail one iota with God, unless they proceed from deep feelings in the heart. Nay, rather they provoke His anger against us, if they come from the lips and throat only, since this is to abuse his sacred name, and hold his majesty in derision (Calvyn, 1845:18).

The song, a form of prayer, in festive dress of poetry and the elevated language of inspiration, raising the congregation to the highest pitch of devotion, and giving it a part in the heavenly harmonies of the saints. This passed immediately, with the Psalms of the Old Testament, those inexhaustible treasures of spiritual experience, edification and comfort, from the temple and the synagogue into the Christian church (Schaff:1997).

\section{Inleiding}

Die sing van die Psalms in veral die erediens is vandag weer, of dalk nog altyd, in die brandpunt. In die Gereformeerde Kerke van Suid-Afrika is daar ' $n$ fel debat rondom die nuwe omdigting. In ander kerke gaan dit soms meer oor die melodieë (modern of nie) en in nog ander oor die moontlike afskeep van die Psalms as deel van die liturgie. Die doel van hierdie artikel is nie om in die eeue-oue debat oor die beryming, melodie en wyses van begeleiding betrokke te raak nie ${ }^{1}$. Die doel is eerder om die sing van die Psalms te

1 Verskeie bronne verskaf oorsigte en besprekings oor die geskiedenis van die sogenaamde Psalmody and Hymnody en die rol van die Psalter in die Christelike kerkmusiekgeskiedenis. Cowley (2003), Adams (1999) Royall (2002) en Barrow (1991) gee byvoorbeeld bondige opsommings. Een van die volledigste en omvangrykste werke is die twee volumes van Hasper (1955; 1976). 
ondersoek aan die hand van die siening dat die Psalms " $n$ gebedsversameling by uitstek is" (Human, 2001:59) en volgens Calvyn "die gebede van die gelowiges" is (D'Assonville, 1997:3). Die sing van psalms is 'n gesamentlike, maar ook persoonlike publieke gesprek met God.

Die Psalms se rol in die liturgie moet opnuut deur liturge en gemeentelede verstaan word. Die kern van die argument is dat daar 'n ernstige heropvoeding en bewusmaking van gemeentelede (en predikers) oor die aard en rol van die sing van die Psalms in die erediens moet plaasvind. Die sing van die Psalms is nie net die sing van liedere nie, dalk met 'n piëtistiese ingesteldheid (biddende sing) nie, maar dit is 'n persoonlike gesprek met God (gebed in die vorm van sang). Psalms, hetsy klaag- of lofpsalms is 'n persoonlike publieke gebed as dit gesing word en bly daarom 'n persoonlike gesprek met God. Die sing van psalms is nie iets wat net uit gewoonte of ritueel gedoen moet word nie. Die vraag ontstaan of die Psalms as "volwaardige liturgiese handelingsvoertuig" waardeur bepaalde liturgiese handelinge vervul word (Strydom 1994:285), kan dien, en of die sing van die Psalms slegs deel moet wees van die erediensgebede en dat ander liturgiese liedere eersgenoemde rol moet vervul?

In hierdie artikel word die rol van die Psalms as gebed eerstens herbevestig. Daarna sal kortliks gekyk word na die standpunte van Calvyn en Luther oor die gebed in die algemeen en die Psalms as gebede. Vervolgens word die standpunte van meer resente skrywers bespreek. Die Psalms in die liturgie word kortliks geëvalueer. Laastens word daar 'n mening uitgespreek oor die sing van die Psalms in die erediens vandag.

\section{Die psalm as gebed}

Die Psalms word reeds in Psalm 72:20 as die gebede van Dawid beskryf. Gebede in die Ou en Nuwe Testament word onder andere deur Smit (1997), O'Kennedy (2000) en Chester (2003) bespreek. Calvyn (1962:16) bespreek die klaag- en lofgebedskarakter van die Psalms deur onder andere van die Psalmboek die volgende te sê:

This it will be worthwhile to point out by the way, that this book we are taught, (and there is nothing more to be desired) not only how familiar access to God may be opened to us, but how we may lawfully and freely lay bare before him the infirmities which a sense of shame prevents our confession to men. Nay further, here also is prescribed most exactly how we may offer 
acceptably the sacrifices of praises, which God declares to be most precious in his sight, and of most sweet savour.

Human (2001) lig die Psalms as gebed toe met spesifieke verwysing na die elemente van die klaagpsalms. Hieruit is dit duidelik dat die essensie 'n gesprek met God is en derhalwe funksioneer die psalm as 'n gebed. Die Rooms Katolieke Kerk (1974:iv) stel dat die "sing" van die Psalms in die erediens 'n publieke gesprek met God namens alle gelowiges is en nie soseer op die individu wat daaraan deelneem, betrekking het nie. Die meeste skrywers verskil van hierdie siening en stel dit dat die sing/bid van die Psalms op 'n baie persoonlike vlak plaasvind (Helberg, 1988:104). Mays (1985) sluit aan by hierdie sienings en wys verder daarop dat gebed en Christologie onlosmaakbaar aan mekaar verbind is en dat die Psalms daarom 'n kernrol speel in die Christelike kerk en liturgie. Hierdie aspekte geld ook as die Psalms gesing word (Anon., 2003a:1).

Om die Psalms as gebed te ondersoek, sal daar eerstens na die standpunte van Calvyn gekyk word.

\section{Calvyn}

Calvyn (1962:16-17) gee in die voorwoord tot sy kommentaar op die Psalms 'n omvangryke verduideliking van die gebedsaard van die Psalms, wat vir hom die kern van die Psalter is. Hy noem dit die anatomie van alle dele van die siel (Calvyn, 1962:16). Die totale gevoelslewe en emosies word hier opgesom. Al die hartseer, verdriet, vrees, twyfel, hoop, sorge, benoudheid - in kort, al die lastige emosies - word volgens Calvyn (1962:16) deur die Heilige Gees in die Psalter lewensgetrou voorgestel. Hy stel dit verder dat in die res van die Skrif die opdragte en gebooie van God deur sy diensknegte oorgedra word. In die Psalter is die profete in gesprek met God en ontbloot hulle al hul mees persoonlike gedagtes en oorreed ook so die lesers tot selfondersoek van al die probleme wat hulle eerder verborge sou wou hou. Die gevolg is "A rare and surpassing benefit, when, every lurking-place having been explored, the heart is brought into the light cleansed from hypocrisy, that noisome pest" (Calvyn, 1962:16).

Calvyn (1845:5-7) gee ses redes waarom gelowiges moet bid:

- Gelowiges se harte moet brandend wees vir die behoefte om God te soek, te dien en lief te hê, terwyl hulle gewoond raak 
daaraan om met elke behoefte na Hom te vlug as die heilige anker.

- Daar moet in gelowiges se harte geen wens of behoefte teenwoordig wees waaroor hulle te skaam sal wees om voor Hom te lê, wanneer hulle hul harte aan Hom ontbloot nie.

- Gelowiges se gebede moet hulle herinner dat al die goeie wat hulle ontvang en waarvoor hulle Hom dank, uit sy hand kom.

- Omdat gelowiges oortuig is dat God hul gebede beantwoord, moet die gebed dien om meer doelgerig oor sy goedheid na te dink (te mediteer).

- Dit wat gelowiges as gebedsverhoring ontvang het, moet in gebed met groot dankbaarheid aanvaar word.

- Die gebed moet aan gelowiges God se voorsienigheid en alomteenwoordigheid bevestig.

Calvyn (1962:16) gee twee redes vir die opregte gebed, naamlik die besef van die bidder se nood en tweedens die geloof in die beloftes van God. Deur die bid van die Psalter word die bidders bewus van hulle geestelike gebreke en geleer om heling daarvoor te soek. Watter aanmoediging ook nodig is om tot God te bid, word in die Psalms verskaf. Calvyn is daarvan oortuig dat nie net die beloftes vir die leser vertel word nie, maar dat die Psalms ook die voorbeeld verskaf van hoe 'n mens moet gereedmaak om te bid. Aan die een kant is die uitnodiging van God en aan die ander kant die gebreke van die mens, sodat verskeie probleme op enige tydstip die persoon kan ontmoedig om te bid. Die biddende omgaan met die Psalms leer die lesers egter om met hierdie probleme te worstel, totdat daar vry en onbevange tot God genader kan word. "And not only so, but though beset by doubts, fearfulness and alarms, we may nevertheless, press forward praying, till we are satisfied with the consolation it affords" (Calvyn, 1962:16). Calvyn (1962:17) som die Psalter dus soos volg op:

Nowhere are there read more evident commendations both of God's singular bounty towards His church, and of all His works; nowhere are recorded so many deliverances, nowhere are the instances of His fatherly providence and care for us set forth more gloriously; lastly, nowhere is the method of praising God delivered more fully, or are we stimulated more powerfully to render him this office of Godliness.

Calvyn se siening oor kerksang is sterk beïnvloed deur Augustinus (Strydom, 1994:36; D’Assonville, 1968). Uit Augustinus se belyde- 
nisse blyk veral drie aspekte ten opsigte van die kerksang (Strydom, 1994:36): Uit sy eie ervaring van die invloed van die sang in Ambrosius se gemeente op sy geestelike lewe, was Augustinus oortuig van die positief-etiese krag van kerksang. Tweedens waarsku hy dat die vleeslike genot en die sintuiglike waarneming van die sang nie die geestelike waarneming van die teksinhoud moet oorheers nie ('n gedagte wat net so deur Calvyn (1845) gebruik word). Derdens moet die lied (melodie) nie die aandag van die sangers opeis nie, maar wel die inhoud van wat gesing moet word. Die melodie moet aanpas by die teksinhoud.

Om hierdie rede pleit Calvyn en Farrel in die Artikels, wat hulle aan die Raad van Geneve op 10 November $1536^{2}$ stuur, dat die Psalms in die kerk gesing moet word omdat die gebede van die gelowiges so koud is (D'Assonville, 1997:4). Calvyn stel verder dat die gemeente weer waarlik moet bid (en nie sonder begrip die priester moet napraat nie) - dit moet gebeur deur middel van die sing van die Psalms. Calvyn onderskei duidelik tussen die twee vorms van openbare (publieke) gebed (Hamersma, 1952:35, 40), naamlik dié met woord alleen en dié met sang. In albei speel die Psalms 'n kernrol. Vir Calvyn is die primêre taak van die tong (spraak/sing) die openbare gebed in die gemeenskap van die gelowiges.

Calvyn (1845:6-9) beskryf vier reëls wat kan meehelp dat korrek gebid kan word. Hierdie reëls geld ook vir die sing van die Psalms (Hamersma, 1952:35). Die eerste reël is ook die hooftema van hierdie artikel, naamlik dat die bidder se hart en gedagtes só ingestel moet wees soos een wat in 'n direkte gesprek met God tree. Tweedens moet die bidder ' $n$ ware besef hê waarvoor gebid word, saam met 'n sterk begeerte om dit te verkry. Calvyn waarsku teen ligsinnige gebed. Weereens beklemtoon dit die regte ingesteldheid op die woorde van die Psalm wat gesing word. Derdens, hy wat voor die aangesig van God verskyn, moet alle selfvertroue en trots aflê en nederig aan God al die eer gee. Dit kan net gedoen word, volgens Calvyn, as daar voorberei word voordat gebid word (en dus deur psalmsing tot God genader word). Vierdens moet die bidder vas glo dat die gebed verhoor sal word. Daarom moet die sanger (bidder) van die psalm weet wat gebid word. Dit wys op die belangrikheid om die psalm se woorde te lees en uit te lig voordat dit gesing word. Die psalm wat gekies word as openbare gemeenskaplike (sang) gebed, moet dus baie versigtig gekies word, sodat dit deur die gemeente as persoonlike openbare gesprek met

De Greef (1993:122) dui hierdie datum aan as 16 Januarie 1537. 
God kan dien. Dit is beslis nie altyd 'n maklike taak nie (Chester, 2003:139).

Hasper (1955:411) wys daarop dat dit vir Calvyn Christelike vreugde was dat die gemeente hulle kan uitdruk in sang waarin die siel 'n ware dialoog met God voer. Hierdie kommunikasie bestaan uit 'n gesprek met God, Hom antwoord, en Hom loof en prys. Dit kan die gemeente, volgens Calvyn, slegs doeltreffend doen in eenstemmige psalmsang in hulle eie taal, verstaanbaar en besield (Hasper, 1955: 411, 533). Die psalmsang wat aan die gemeente toevertrou was, was vir Calvyn die bevestiging van die amp van die gelowige. Deur psalmsang kry die gemeente ' $n$ beslissende aandeel in die erediens (Hasper, 1955:658). Vir Calvyn was die gesonge gebed (psalms) van die gemeente, die gesonge lofverheffing en smeekbede, die uiting van die kerk van alle eeue (Hasper, 1976:15).

Calvyn se siening kan soos volg opgesom word: "Music is a gift of God, suitable for public worship, but it must be adapted to a worship setting" (De Greef, 1993:129). Die doel van hierdie kort bespreking was om aan te dui dat Calvyn die sing van Psalms as gebede in die erediens as 'n baie belangrike saak gesien het. Gesonge gebede was vir hom net so belangrik of selfs belangriker as gesproke gebede (Strydom, 1994:75). Dit is duidelik dat hy dit as 'n persoonlike gesprek met God beskou het. In aansluiting hierby sal Luther se sienings oor die Psalm as gebed bespreek word.

\section{Luther}

Martin Luther het 'n sistematies afgebakende gebedsleer gehad (Damerau, 1977:14). Hy wys ook op die belangrike rol wat die Psalms by gebed speel (Vajta, 1983:287-291). Hy huldig dieselfde siening as Calvyn en beweer:

... but this is true indeed that such prayers as have been offered hitherto when men were babbling and bawling in the churches were no prayers. For such external matters, when they are properly observed, may be a good exercise for young children, scholars, and simple persons, and may be called singing or reading, but not really praying (Luther, 1921:741).

Luther beklemtoon ook die rol wat geloof by die gebed speel (Lohse, 1999:202; Führer, 1983:23, 116). Luther stel dat sonder geloof, aan die kant van die bidder, verloor God in die oog van die bidder van sy eienskappe, soos sy glorie, wysheid en regverdigheid. Die twee beginsels wat hier geld, is dat die gebede in gehoorsaamheid aan God gebring moet word en tweedens in die vertroue dat God dit sal 
verhoor (Luther, 1921:743; 1994:4; Junghans, 1983). In sy bekende werk $A$ simple way to pray for a good friend (1955), stel Luther verdere beginsels vir die gebed wat ook so toegepas kan word op die ernstige bid (sing) van die Psalms in die erediens (kyk o.a. Anon., 2003b:6). Wat veral van belang is, is sy oproep om die belangrikheid en dringendheid van die gebed te onthou en om te konsentreer tydens die gebed, terwyl die pogings van die duiwel om die (konsentrasie) gebed te onderbreek, weerstaan moet word. Luther wys daarop dat die uitdrukking selah in die psalms die bidder dwing om eers te reflekteer op die woorde van die psalm, sodat daar duidelik verstaan kan word wat die Heilige Gees sê met die geuiterde woorde (Bonhoeffer, 1999:7).

Hierdie standpunte moet egter duidelik onderskei word van Luther se breër siening oor die kerklied. Strydom (1994:60-61) som die funksies wat gemeenstesang in die erediens volgens Luther moes vervul, soos volg op: Gemeentesang moet die lof van God verkondig, die toewyding en vroomheid van Christene bevorder, die verkondiging van die evangelie dien en die jeug opvoed deur by die jeug 'n liefde te kweek vir die eredienslied as teenvoeter vir oppervlakkige straatliedjies.

Samevattend kan gestel word dat die gereelde bid (en sing) van die Psalms vir Luther so belangrik was, dat hy dit gelykgestel het aan die ander gebooie van God (Luther, 1921; Bonhoeffer, 1999:24). Hy beklemtoon die persoonlike aard daarvan en wys hoe belangrik konsentrasie en die regte ingesteldheid is. Vervolgens sal kortliks verwys word na ander skrywers se sienings oor die Psalms se funksie as gebed.

\section{Ander skrywers}

Brueggemann (1988:3) stel dat lofprysing 'n wesentlike daad (constitutive act) van die geloofslewe is. Hy sluit aan by Westermann (1965:22) en Von Rad (1962:362) en toon aan dat lofprysing 'n reaksie op die realiteit, mag en aktiwiteit van God is en dat die Psalms die lofprysende antwoord van die gelowiges op hierdie realiteit is. In aanbidding vorm die Psalms nie net die individu se geloof nie, maar ook dié van die gemeenskap. Die Psalms neem die gelowige weg van die eng konsentrasie op sy eie besorgdheid van wat hy/sy van God kan kry, na 'n voller visie van hom/haarself as deel van die nood van die wêreld (Picket, 2002:i). Lofprysing deur die Psalms is volgens Brueggemann (1988:4) nie net die metode om met God te praat nie, maar dit is 'n daad wat die teologiese wêreld waarin die bidder leef, skep. Hy brei uit oor die persoonlike aard van 
die gebruik van die Psalms in gebed (Brueggemann, 2002:40-42) en wys daarop dat ook die gemeenskaplike (lof- en klaag-)psalms 'n belangrike rol in die individu se lewe speel. Die gemeenskaplike sang maak nie van die bid (sing) van hierdie psalms 'n onpersoonlike aksie nie. Inteendeel, die individu se assosiasie met en opdra van die "gemeenskap" se lot en behoeftes in gebede aan God is ' $n$ baie belangrike taak in elke persoon se geloofslewe. Nogtans bly dit 'n persoonlik gesprek met God. Brueggemann (2002:58) toon aan dat hierdie persoonlike gebruik (presentation) van die Psalms vandag 'n outentieke spiritualiteit aangeneem het en waarlike gemeenskap (communion) met God is.

Wat 'n persoon sê in hierdie persoonlike gesprek met God hang direk af van sy omstandighede (Brueggemann, 2002:58). Brueggemann (1982:18) wys dat soos die gelowige begin om die psalm te sing en te bid, dit baie belangrik is om bedag te wees op die eenvoudige, passievolle en dapper welsprekendheid van die gesprek met God. Crenshaw (2001:59) sluit hierby aan en wys hoe die sintuiglike taal van die Psalms (voel met die hart, kyk met die oë, ensovoorts) die intimiteit tussen God en die gelowige versterk. Volgens hom is dit hierdie terme wat sorg vir die kombinasie van morele en rituele konsepte. Bonhoeffer (1999:3) ondersteun hierdie stellings en wys daarop dat hierdie persoonlike gesprek net kan plaasvind omdat Christus vir/namens die gelowiges bid. Die gelowige moet dus die woorde wat gebid (gesing) word, ondersoek met die gesindheid van nie wat-het-dit-met-hom/haar-te-doen nie, maar, van wat-het-dit-met-God-te-doen. Hierdie besef (Brueggemann, 1982:3) veroorsaak ook dat die openbare gebed (sing van 'n psalm met die gemeente) nog 'n persoonlike gesprek met God bly, al handel die woorde nie altyd oor presies dit wat die gelowige op daardie stadium in sy/haar hart ervaar nie.

Die psalm bly die lied van gebed en liefde tussen Jesus die Koning en die kerk wat aan hom behoort (Brueggemann, 1982:13). Wanneer gelowiges die Psalms lees (sing), mediteer hulle en deel hulle die gedagtes en skommelende emosies saam met die volk van God in die Ou Testament - die mense aan wie God homself bekend gemaak het. Dan deel hulle ook in Israel se belewing van God (Anglikaanse Kerk, 1977:10). Old (1995:57) stel dat:

a generous use of Psalms in worship, either as responsive readings, as anthems, or sung in metrical version by the whole congregation, has a very important theological principle behind it. Prayer is in the final analysis a gift of God, a divine work of the Holy Spirit crying out in us. 
In hierdie deel is aangetoon hoe enkele skrywers die sienings van Calvyn en Luther oor die sing van Psalms, as 'n persoonlike gebed, onderskryf. Vervolgens sal kortliks gekyk word na die Psalms in die liturgie. Die klem sal val op die sing van die Psalms as gebed, maar daarmee word nie te kenne gegee dat die Psalms nie ook deel van ander dele van die liturgie, soos die votum, Wet, vryspraak en seën, kan wees nie.

\section{Psalms in die liturgie}

Strydom (1994:135) wys op die wêreldwye, ekumeniese, liturgiese beweging wat as onderdeel ook die vernuwing van die liturgiese sangpraktyk voorstaan. Dit geskied onder andere deur die "hartlike oortuigende gemeentesang" - juis omdat die sang die liturgiese handelsvoertuig en kommunikasiemedium is. Strydom (1994:136) stel verder dat die integriteit en geloofwaardigheid van die erediens onder andere afhang van die gemeenstesang. Die musiek moet pas by die bepaalde handeling waarvoor dit op 'n bepaalde moment in die erediens as voertuig dien (Strydom, 1994:251, 285). Die liturgiese sang is ook 'n volwaardige kommunikasiemedium, omdat die gelowiges al singende die evangelie aan mekaar kommunikeer (Strydom, 1994:285).

Tog stel Strydom (1994:159), aan die ander kant, dat die Skrif die finale toetssteen vir die liturgie is (vgl. ook Brown, 1991). Die Skrif moet volgens hom te alle tye die maatstaf wees waaraan die inhoud van die liturgiese gebede en liedere, sowel as die prediking, gemeet word. Die erediensmusiek moet nie net vermaak nie, maar moet ook geestelik opbou (Strydom, 1994:169). So word die erediens se dialogiese aard beklemtoon as 'n wederkerige ontmoeting tussen God en sy volk as verbondsgenote, waarin dinamiese gemeentesang 'n belangrike rol speel (Strydom, 1994:191).

Uit hierdie bespreking kom die dilemma van die gebruik van die Psalms binne die liturgiese handelinge duidelik na vore. Gemeentesang in die erediens moet sekere liturgiese handelinge en stemming skep, deur onder andere hartlike en oortuigende sang. Die sing van die Psalms is ook 'n gesamentlike, maar persoonlike openbare gesprek met God. Die skrywers hierbo waarsku baie ernstig teen die onbedagte sing of die sing van die Psalms net omdat 'n lied gesing moet word om byvoorbeeld 'n stemming te skep of spiritualiteit te bevorder. Hoe kry die liturg hierdie twee sake versoen? Kan die Psalms alleen in al die behoeftes wat sang in die liturgie moet vervul, voldoen, of moet die sing van die Psalms byvoorbeeld eerder deel wees van die erediensgebed? 
Bogenoemde vraag word deur Lourens (2000) ondersoek. Hy onderneem 'n uitvoerige studie oor die gebed as kommunikatiewe handeling in die erediens. Hieruit maak hy onder andere die volgende gevolgtrekkings oor die erediensgebed (Lourens, 2000: 239-252):

- Die gemeente behoort aan die erediensgebed deel te neem as húl gebed.

- Die gemeente se deelname aan die erediensgebed behoort 'n reaksionêre karakter te vertoon.

- Sowel die liturg as die gemeente moet ingestel wees op dubbele interaktiewe kommunikasie.

- Die erediensgebed behoort die indruk te wek van solidariteit tussen die voorganger en die gemeente.

- Die erediensgebed behoort as geloofshandeling ingerig te word.

- Die erediensgebed behoort op 'n kommunikatiewe wyse uitdrukking te gee aan die gemeente se geloofsgemeenskap.

- Die hele erediensgebed behoort as aanbiddingsdaad ingerig te word.

- Erediensgebede moet eskatologies ingerig word.

- Erediensgebede behoort deur bekende beelde en ervarings visualiserend verwoord te word.

- God behoort as Vader aangeroep te word.

- Gebede behoort 'n skerp omlynde trinitariese karakter te openbaar.

- Lofprysing behoort regstreeks en baie persoonlik direk op God te fokus.

- Danksegging behoort klem te lê op die kommunikatiewe betuiging van erkentlikheid teenoor God op geestelike en liggaamlike terrein.

- Danksegging moet die gemeente se erkentlikheid ten opsigte van God se voorsienigheid en die aktualisering van Sy heerskappy konkreet verwoord.

- Sondebelydenis behoort die erns en omvang van sonde te erken en te bely.

- Sondebelydenis moet die herstel van verhoudings in die oog hou. 
- Smeking en klag behoort spesifiek op geestelike terrein gerig te word.

- Gelowiges behoort met die verwagting op verhoring te bid op grond van God se wil.

Uit die bespreking van die Psalms as gebed is dit duidelik dat die sing van die Psalms al die kriteria vir die erediensgebed, wat in die voorgaande paragrawe deur Lourens gestel word, bevredig. Dit beteken nie dat die Psalms die erediensgebed moet vervang nie. Die bespreking herbevestig net die spesifieke aard van die psalm as liturgiese lied. Bingle (2000:34,143,144) lig hierdie aspek toe en maak die volgende gevolgtrekkings oor die liturgies-himnologiese betekenis van die liturgiese lied volgens die Ou en Nuwe Testament. Die gevolgtrekkings ten opsigte van die verhouding openbaringdogmavorming-doksa-uiting in die liturgiese lied, word soos volg opgesom:

- Liturgiese sang is gerig op die God van die openbaring. Sy verlossing is die rede vir die himniese aktiwiteit.

- Dié openbaring se betekenis word verder ontsluit (geaktualiseer) in die responsiewe taal van die sang wat gelowig opklink uit die keel van die sanger.

- Die lied maak van die openbaringsfeit 'n werklikheid in die geloof. God se openbaringshandeling word lewende dogma.

- Die belydenisinhoud van die lied word ook deur die openbaring gegee. Die kern hier is die monoteïsme wat die deugde van God, soos geopenbaar in die skepping en die verlossingsgeskiedenis, besing.

- Die liturgiese sang is 'n gemeenskaplike handeling, wat 'n algemene belydenis uitdruk. Die sang het egter 'n sterk persoonlike karakter. Die liturgiese lied is nie 'n "ek-lied" wat uit muse of ontroering ontstaan nie, maar is 'n "ons-lied" wat doksologies uit gemeenskaplike, lewende dogma onstaan.

- Die liturgiese lied se doksa-uiting gaan nie net oor die oorwinnende koningskap van die Enige God nie, maar ook die finale oorwinning wat kom.

Hierdie afdeling het die rol bespreek wat die sing van die Psalms as erediensgebed en as liturgiese lied speel. Ten slotte gaan daar, in die lig van hierdie bespreking, na die sing van Psalms in die erediens vandag gekyk word. 


\section{Implikasies vir vandag}

Uit bogaande bespreking is dit duidelik dat daar baie goed besin moet word oor die gebruik van die Psalms as liturgiese lied. Die Psalms kan nie sommer aangewend word as liturgiese voertuig, net omdat dit dalk paslik is om sang op 'n seker punt in die liturgie te gebruik nie. Die gebruik van psalmsang terwille van die "vloei" van die liturgie, moet baie sterk afgewys word. Die sing van die Psalms is 'n gebed - 'n gesprek met God. Dit is nie slegs die sing van 'n lied met 'n piëtistiese/biddende ingesteldheid nie. Hieruit kan die gevolgtrekking gemaak word dat die sing van 'n psalm terwyl die kollekte opgeneem word, ernstig bevraagteken kan word. Normaalweg sien die gemeente die sing van 'n liturgiese lied onder die kollekte as iets om die gemeente mee besig te hou. Indien die gemeente wel hulle dank betoon of die armes aan God in die psalm opdra, kan die sing van die psalm dalk geregverdig word. Dit bly egter 'n vraag of die nodige konsentrasie en respek vir God onder hierdie omstandighede moontlik is. Dieselfde argument kan ook geopper word by die sing van 'n psalm terwyl die babas wat gedoop moet word, die kerk ingebring word. Die sing van 'n psalm (gewoonlik Psalm 23) terwyl die diakens die Nagmaalstafel voorberei, kan dieselfde probleem veroorsaak, behalwe as die liturg baie duidelik vir die gemeente aandui dat hulle nou in gesprek tree met God. In hierdie gesprek dank hulle Hom vir die feit dat sy tafel vir hulle in gereedheid gebring word en hulle die Nagmaal gaan vier. Die sing van 'n psalm wanneer gemeentelede na of van die Nagmaalstafel loop, kan ook aanleiding gee tot hierdie probleem. Dit is goed bekend dat die "sing" van psalms 'n integrale deel van Israel se toetrede tot en opkoms na die tempel (bv. Ps. 15, 24) en tydens offers uitgemaak het (bv. Ps. 120-134). Hulle het egter die doel en gespreksaard daarvan met God baie duidelik verstaan. Ander liturgiese liedere, byvoorbeeld Skrifberymings, kan moontlik sonder bogenoemde probleme aangewend word as liturgiese "handelingsvoertuie".

Liturge dra baie keer by tot die feit dat die begryp van die gebedsaard van die psalmsang onder gemeentelede vervaag. Bingle $(2000: 160,161)$ waarsku dan ook ernstig teen die gebruik, deur die liturg (prediker), van woorde soos "ondertussen" of "vervolgens" gaan die gemeente saamsing nadat 'n spesifieke ander liturgiese handeling soos die gebed of Skriflesing plaasgevind het. Dan dui dit net op ' $n$ verposing, totdat die volgende (belangriker handeling) gaan plaasvind. 
Daar is 'n baie fyn, dog duidelike, skeidslyn tussen die sing van 'n lied waarvan die woorde pas by die preek en 'n persoonlike openbare gesprek met God waar die singer/bidder 'n spesifieke versoek tot God rig. Die liturg moet baie goed aan die gemeente verduidelik waarom hierdie "gesprek met God" gevoer word na aanleiding van die bepaalde teksvers of hooftema van die preek. Teen die blote keuse van 'n psalm waarvan die woorde naastenby "verband hou" met die teksvers of tema van die preek, wat as "antwoord" op die preek of Skriflesing gesing word, moet gewaarsku word, omdat die innerlike gesteldheid van die hart by die gebed van die hoogste belang is. As die gelowige bid stel hy/sy hom/haar voor die aangesig van die Here. Dit kan nie geskied sonder eerbied vir die majesteit van God nie (De Klerk, 1955:20). Brueggemann (2002:58) stel dit dat wat gesê word in die gesprek met God afhang van die spesifieke omstandighede of saak wat aan die orde is. Dit is ook belangrik om te onderskei of die psalm van die "ou" (las van die sonde) of "nuwe" (verlossing) oriëntasie praat (Brueggemann, 2002:49).

Die gebruik van die Psalms as liturgiese lied plaas 'n baie groot verantwoordelikheid op die liturg, om te waak dat die gebedskarakter as persoonlike openbare gesprek met God nie misken word nie. Daar moet gewaak word dat daar nie verval word in 'n onnadenkende en oneerbiedige gewoontehandeling nie.

\section{Slot}

Hierdie artikel het die Psalms as gebede ondersoek. Daar is aangetoon dat die kerkvaders en navorsers oor die eeue dit eens is omdat die sing van die Psalms 'n persoonlike openbare gebed is, dit so met die nodige erns deur liturg en gemeente gedoen moet word. Die kerngedagte is aangesien die sing van die Psalms ' $n$ persoonlike gesprek met God is (daar word singende gebid), 'n piëtistiese ingesteldheid (biddende sing) by die sing van die Psalms nie korrek/voldoende is nie.

Om die gesprek met God op 'n persoonlike vlak te hou en die nodige spiritualiteit te bewerkstellig, is dit noodsaaklik dat die liturg die rol en verband van 'n spesifieke psalm só uitlig dat die individuele gemeentelid dit as 'n persoonlike gesprek met God kan ervaar, wanneer die psalm gesing word. Daarom moet die sanger (bidder) van die psalm weet wat gebid word. Die toeligting van die inhoud wys op die belangrikheid om die psalm se woorde uit te lig voordat dit gesing word. Die blote voorlees van die Psalmvers(e) is meestal nie voldoende nie. Hierdie aspek blyk ook duidelik uit 
Calvyn se reëls vir korrekte gebed. Brueggemann (1982:17 en 20) stel dit verder dat, wanneer die psalms in 'n geroetineerde konvensionele gebedslewe gebruik word, uit gewoonte of vanweë moegheid of stompsinnigheid, die doel van die psalms gemis word. "Tradition is the living voice of the dead; traditionalism is the dead voice of the living" (Cowley, 2003:1).

Teen die blote piëtisties ingestelde sing van die Psalms as liturgiese lied of as koppeling van liturgiese handelinge, moet baie ernstig gewaak word. Die gelowige se ervaring van oorweldig wees, byna vernietig wees, maar ook die verrassende aspek van 'n nuwe lewe in Christus, bemagtig hulle om met God in gesprek te tree deur die Psalms te bid of te sing (Merrill, 1998:vi). Die sing/bid van die Psalms as persoonlike openbare gesprek met God, moet baie goed deur liturg en gemeente verstaan word.

Thus I suggest that most of the Psalms can only be appropriately prayed by people who are living at the edge of their lives, sensitive to the raw hurts, the primitive passions, and the naïve elations that are the bottom of our life. For most of us, liturgical and devotional entry into the Psalms requires a real chance of pace. It asks us to depart from the closely managed world of public survival, to move into the frightening, healing world of speech with the Holy One (Brueggemann, 1982:20).

\section{Geraadpleegde bronne}

ADAMS, R. 1999. Focus on the Reformed tradition: The Psalter. Sabbath Rest, 4(2):11-19. http://joshua.sfts.edu/liebert/psalmresources/The\%20Psalter. cfm [28 Jul. 2003].

ANGLIKAANSE KERK. 1977. The Psalms: A new translation of worship. London: Collins.

ANON. 2003a. Waarom Psalms in die erediens behoort gesing te word. http://www.geocities.com/ResearchTriangleLab/7697/art10.html [18 Jun. 2003].

ANON. 2003b. Luther on prayer. http//:sermons.made4usa.com/Notes/ LutherOnPrayerNo3.html [7 Nov. 2003].

BARROW, R. 1991. Psalm singing in Scripture \&history. Christian Reformation Today, Jul-Oct. http://www.swrb.com/newslett/actualnls/CRTPsSing.htm [18 Jun. 2003].

BINGLE, J.P. 2000. Die verhouding tussen openbaring, dogmavorming en doksa-uiting in die liturgiese lied. Potchefstroom: PU vir CHO. (Th.Mverhandeling.)

BONHOEFFER, D. 1999. The Psalms: Prayer book of the Bible. (Vert. Sister Isabel Mary.) 5e Uitgawe. Oxford: SLG.

BROWN, J. 1991. The Psalms of David in Metre. Presbyterian Heritage Publications. http://www.swrb.com/newslett/actualnls/Psalter1.htm [18 Jun. 2003]. 
BRUEGGEMANN, W. 1982. Praying the Psalms. Winona: Saint Mary's Press.

BRUEGGEMANN, W. 1988. Israel's praise: Doxology against idolatry and ideology. Philadelphia: Fortress.

BRUEGGEMANN, W. 2002. Spirituality of the Psalms. Minneapolis: Fortress.

CALVYN, J. 1845. Institutes of the Christian Religion. (Vert. H. Beveridge.) Boek III. http://www.gracepleasanton.com/library/on_prayer.htm [28 Jul. 2003].

CALVYN, J. 1962. A commentary on the Psalms. (Vert. Arthur Golding; hersien deur T.H.L. Parker.) Vol. 1. Londen: Clarke.

CHESTER, T. 2003. The message of prayer: Approaching the throne of grace. Leicester: Inter-Varsity. (The Bible Speaks Today: Bible Themes Series.)

COWLEY, T. 2003. Observations on the history of Psalmody and Hymnody in Christian church music. http://www.reformedprescambridge.com/articles/ Observations_on_theHistory_of_Psalmody_and_Hymnody_in_Christian_ Church_Music. Pdf [8 Jun 2003].

CRENSHAW, J.L. 2001. The Psalms: An introduction. Grand Rapids: Eerdmans.

D'ASSONVILLE, V.E. (snr.). 1968. John Knox and the Institutes of Calvyn. Durban: Drakenberg Press. (Ph. D. thesis.)

D'ASSONVILLE, V.E. (snr.). 1997. Die Psalmberymings van Calvyn (1539) en Totius (1937). Afrikaanse vertaling deur die skrywer van sy bydrae in: Ordenlich und fruchtbar - Festschrift für Willem van 't Spijker, Leiden. http://home.spg.co.za/bogaarts/Psalmberymings.Totius.htm [18 Jun. 2003].

DAMERAU, R. 1977. Luthers Gebetslehre 1515-1546. Marburg: Marburg Universität.

DE GREEF, W. 1993. The writings of John Calvin: An introductionary guide. (Vert. L.D. Bierma.) Grand Rapids: Baker Books.

DE KLERK, P.J.S. 1955. Die gebed in die heilige Skrif. Pretoria: Van Schaik.

FÜHRER, W. 1983. Das Wort Gottes in Luthers Theologie. Göttingen: Vandenhoeck \& Ruprecht.

HAMERSMA, J. 1952. John Calvyn on Christian worship. New York: Union Theological Seminary. (M. dissertation.)

HASPER, H. 1955. Calvijns beginsel voor den zang in den eredienst: Verklaard uit de heilige Schrift en der geschiedenis der kerk. Deel I. 's-Gravenhage: Nijhoff.

HASPER, H. 1976. Calvijns beginsel voor den zang in den eredienst: Verklaard uit de heilige Schrift en der geschiedenis der kerk. Deel 2. Groningen: De Vuurbaak.

HELBERG, J.L. 1988. Die Here regeer. Pretoria: NG Kerkboekhandel.

HUMAN, D.J. 2001. Gebed: 'n Proses wat verandering bemiddel. Verbum et Ecclesia, 22(1): 58-71.

JUNGHANS, H., Red. 1983. Leben und Werk Martin Luthers von 1526 bis 1546. Festgabe zu seinem 500. Geburtstag. Band 1 und 2. Göttingen: Vandenhoeck \& Ruprecht.

LOHSE, B. 1999. Martin Luther's theology: Its historial and systematic development. (Vertaal deur R. Harrisville.) Minneapolis: Fortress.

LOURENS, P.K. 2000. Gebed as kommunikatiewe handeling in die erediens. Potchefstroom. PU vir CHO. (Th. M-verhandeling.) 
LUTHER, M. 1921. The large catechism. Vert. F. Bente \& W.H.T. Dau. (In Triglot Concordia: The symbolical books of the Ev. Lutheran Church. St. Louis: Concordia Publishing House.) http://ctsfw.edu [7 Nov. 2003].

LUTHER, M. 1955. A simple way to pray for a good friend. (In Tappert, T.G., ed. Luther: Letters of spiritual council. Philadelphia: Westminster Press. Library of Christian Classics. Vol. XVII.)

LUTHER, M. 1994. The small cathechism. Vertaal deur R.E Smith. ProjectWittenberg. Concordia Theological Seminary. http://ctsfw.edu [7 Nov. 2003].

MAYS, J.L. 1985. Prayer and Christology: Psalm 22 as perspective on the Passion. Theology Today, 42(3):1-8. http://theologytoday.ptsem.edu/oct 1985/v42-3-article4.htm [28 Jul. 2003].

MERRILL, N.C. 1998. Psalms for praying: An invitation to wholeness. New York: Continuum.

O'KENNEDY, D.F. 2000. Gebed in die Ou en Nuwe Testament: 'n Vergelykende studie. In die Skriflig, 34(4): 535-555.

OLD, H.O. 1995. Leading in prayer: A workbook for ministers. Grand Rapids: Eerdmans.

PICKET, B. 2002. Songs for the journey: The Psalms in life and liturgy. London: Longman.

ROOMS-KATOLIEKE KERK. 1974. The divine office: The liturgy of the hours according to the Roman rite. Glasgow: Collins.

ROYALL, D.W. 2002. The Genevan tunes: An introduction. Christian Renewal, 20(12). http://spindleworks.com/library/royall/genevan.htm. [12 Jun. 2003].

SCHAFF, P. 1997. History of the Christian church. Oak Harbor:Logos Research Systems. (Gekorrigeer en bygewerk deur The Electronic Bible Society, 1988, Dallas.)

SMIT, E.J. 1997. Die voorkoms en betekenis van gebede in die Ou Testament. In die Skriflig, 31(4): 437-451.

STRYDOM, W.M.L. 1994. Sing nuwe sange nuutgebore: Liturgie en lied. Bloemfontein: NG Sendingpers.

VAJTA, V. 1983. Luther als Beter. (In Junghans, H., Red. Leben und Werk Martin Luthers von 1526 bis 1546. Festgabe zu seinem 500. Geburtstag. Band 1 und 2. Göttingen: Vandenhoeck \& Ruprecht.)

VON RAD, G. 1962. Old Testament theology. New York: Harper \& Row.

WESTERMAN, C. 1965. The praise of God in the Psalms. Richemont: John Knox.

Key concepts:

psalm singing: talking to God

Psalms - as book of prayers

Sleutelbegrippe:

Psalms - as gebedeboek

psalmsing: gesprek met God 
